\title{
Life satisfaction and other determinants of eating behaviours among women aged 40-65 years with type 2 diabetes from the Krakow population
}

\author{
Maria Gacek ${ }^{1}$, Agnieszka Wojtowicz² \\ ${ }^{1}$ Department of Sports Medicine and Human Nutrition, Institute of Biomedical Sciences, University School of Physical Education \\ in Krakow, Poland \\ ${ }^{2}$ Department of Psychology, University School of Physical Education in Krakow, Poland
}

\begin{abstract}
Introduction: A rational dietary model is one of the key aspects in the treatment of type 2 diabetes.

Aim of the study: The study aimed to analyse the frequency of consuming selected groups of food products among women aged 40-65 years with type 2 diabetes, depending on age, BMI, duration of disease, and level of life satisfaction.

Material and methods: The study was carried out among 276 women using the author's specially designed questionnaire (metric data, duration of diabetes) and the Satisfaction with Life Scale (SWLS). We assessed BMI values on the basis of measurements of somatic indicators (body mass and height). Statistical analysis was performed using Pearson's $r$ and Spearman's R correlation coefficients via the SPSS programme (significance level of $\alpha=0.05$ ).

Results: Among the women with type 2 diabetes we observed nutritional deficiencies, in particular a low frequency of consuming the recommended product groups (vegetables, fruit, legume seeds, whole-grain cereals, dairy products with reduced fat content, and nuts). The scale of rational dietary choices among women increased along with age and perceived life satisfaction. As the time from diagnosis passed, this scale decreased. A decrease was also noted along with the increase in BMI.

Conclusions: The frequency of consuming some product groups shows a significant relationship with age, $\mathrm{BMI}$, duration of disease, and the level of life satisfaction among women aged 40-65 years with type 2 diabetes.
\end{abstract}

Key words: type 2 diabetes, eating behaviours, women, life satisfaction, physical activity.

\section{Introduction}

In the complex aetiopathogenesis of non-insulindependent diabetes mellitus (T2DM), a key role, in addition to genetic factors, is played by behavioural conditions, including improper diet and low levels of physical activity, promoting obesity and insulin resistance [1, 2]. Excessive body mass also increases the risk of developing other health threats, including metabolic syndrome and its complications [1, 3-10]. Epidemiological studies have proven that one of the groups at increased risk of degenerative diseases, including metabolic ones, are women of menopausal age $[11,12]$.

Achieving the goals of diabetes treatment, including balancing carbohydrate metabolism, lipid profile normalisation, maintenance of normal blood pressure, and proper body mass, are conducive to pro-health behaviours, as well as rational dietary choices and physical activity [1321]. Primary and secondary prevention of type 2 diabetes is supported by a diet rich in high-density foods, including vegetables and fruits, whole-wheat cereals, dairy products with reduced fat content, fish and vegetable oils, and nuts, with the restriction of animal fats, red meat, highlyprocessed cereals, as well as sweet and salty snacks [17]. An important element of therapeutic treatment in type 2 diabetes is a diet with the restriction of easily digestible carbohydrates, high IG products. An aspect of therapy for type 2 diabetes is also recreational physical activity, which improves energy balance, promotes body mass reduction, and further optimises blood lipid profile and carbohydrate metabolism, reducing health risks associated with obesity and diabetes [22]. American research has confirmed that the explanation for the highest number of deaths due to diet-related cardiometabolic reasons could be high intake of sodium and low consumption of nuts, highly processed meat, fish and seafood (omega-3), and fruit and vegetables [23]. 
Pro-health behaviours, including those related to nutrition, are determined by a broad spectrum of socio-economic, cultural, and personality-dependent factors [24, 25]. One of the personal resources associated with human health culture is sense of life satisfaction, understood as a subjective indicator of quality of life, or otherwise, as a cognitive aspect of satisfaction from life, which determines the degree of positively valuing life, i.e. to what extent a given person has satisfied his/ her aspirations [25]. Previous studies have shown relationships between the level of life satisfaction and the dietary behaviours of women at perimenopausal age $[26,27]$, including hypertension [28]. Within this context, research was undertaken on the predictive role of sense of life satisfaction in relation to the dietary choices of women with type 2 diabetes.

Assuming the stance that in the treatment of diabetes, in addition to the use of hypoglycaemic medications (or less often, insulin), an important role is played by a pro-health lifestyle, including rational dietary choices and undertaking recreational physical activity, research was carried out regarding nutritional behaviours and their selected determinants among women aged 4065 years with diagnosed type 2 diabetes mellitus. Our study aimed to analyse the frequency of consuming selected groups of food products (recommended and contraindicated) depending on age, duration of disease, BMI index, and the level of life satisfaction among women aged 40-65 years with type 2 diabetes from the Krakow population.

\section{Material and methods}

Execution of the study was among a group of 276 women aged $40-65$ years $(47.92 \pm 5.53)$ from the Krakow population with diagnosed type 2 diabetes. The author's specifically created validated questionnaire on the frequency of consuming selected groups of food products was used during the research. The frequency of consumption of product groups was assessed on an ordinal scale from 1 to 7 (1: never, 2: once a month, 3: several times a month, 4: 2-3 times a week, 5: 4-6 times a week, 6: once a day, and 7: several times a day). In the interpretation of average values of the frequency of consuming 22 particular food products, we adopted the following ranges: several times a day (7.00-6.50), once a day (6.49-5.50), 4-6 times a week (5.49-4.50), 2-3 times a week (4.49-3.50), several times a month (3.49-2.50), once a month (2.49-1.50), and never (1.49-1.00). The demographic part of the questionnaire included questions about the following: age, place of residence, other comorbidities, how to control glycaemia (hypoglycaemic agents vs. insulin), declared compliance with medical recommendations, health self-assessment, and duration of diabetes (seven questions in total). The standardised Satisfaction with Life Scale (SWLS) by Diener, Emmons,
Larsen, and Griffin and later adapted by Juczyński was used to measure the cognitive aspect of satisfaction from life [25]. The SWLS, containing five statements with a seven-degree answer scale (1 - "I totally disagree"; 7 - "I totally agree"), is constructed in such a way that the higher the test result (within the range of 5-35 points), the higher the sense of life satisfaction. The reliability of the scale totals 0.81 . The BMI value of women was assessed on the basis of somatic indicator measurements (body mass and height) using standard measuring tools (Tanita TBF-300P electronic scale and anthropometric altimeter). Anthropometric measurements were performed in the morning, in fasting state. The research was carried out, taking the standards of the Declaration of Helsinki into account, after obtaining the informed consent of the studied women. The original questionnaire and test results were administered by the authors of the work.

Women with diabetes declared co-occurrence of other chronic diseases, such as: hyperlipidaemia (56.5\%), hypertension $(46.0 \%)$, obesity $(53.3 \%)$, hypothyroidism $(21.7 \%)$, coronary heart disease $(6.2 \%)$, and osteoporosis (5.1\%). They rated their health as average (49.3\%) and good $(44.9 \%)$, but rarely as very good $(2.5 \%)$ or poor (3.3\%). Women mostly took oral hypoglycaemic drugs (79.3\%) to regulate blood glucose level, and less often, insulin. $35.1 \%$ of the studied women declared strict adherence to medical recommendations.

Statistical analysis was conducted using Pearson's $r$ and Spearman's $R$ rank correlation via the SPSS programme, assuming a statistical significance level of $\alpha=0.05$.

Data distribution in terms of demographic and somatic characteristics and other variables explaining the frequency of consuming certain products among women with type 2 diabetes is presented in Table 1.

\section{Results}

Correlation analysis showed that along with the age of the studied women, there was an increase in BMI index, duration of diabetes, and level of life satisfaction. We observed a positive correlation between the duration of the disease and the BMI index. In addition, along with the increase in BMI index and the duration of diabetes, a decrease in the level of life satisfaction of the examined women occurred $(p<0.01)$ (Table 2 ).

Assessment of the frequency of consuming selected groups of food products has shown that women with type 2 diabetes most often (daily, $\mathrm{Me}=7$ ) drink mineral water. At a rate of 4-6 times a week $(M e=5)$, they consumed: various vegetables, green vegetables, fruit, pork, and poultry. Usually, 2-3 times a week $(\mathrm{Me}=4)$, they consumed: light cereal products, semi-skimmed or low-fat milk and cottage cheese, eggs, and butter. Frequently, i.e. several times a month $(\mathrm{Me}=3)$, the following were included in the diet: legume seeds, whole- 
Table 1. Characteristics of the group of women under study in terms of demographic and somatic features, duration of disease, and level of life satisfaction (descriptive statistics)

\begin{tabular}{|c|c|c|c|c|}
\hline \multirow[t]{2}{*}{ Variables } & \multicolumn{4}{|c|}{ Descriptive statistics } \\
\hline & Minimum & Maximum & M & SD \\
\hline Age (years) & 40.00 & 65.00 & 47.92 & 5.52 \\
\hline Body mass (kg) & 59.00 & 120.00 & 75.84 & 13.63 \\
\hline Body height (cm) & 154.00 & 190.00 & 168.33 & 8.43 \\
\hline BMI $\left(\mathrm{kg} / \mathrm{m}^{2}\right)$ & 21.00 & 44.07 & 26.71 & 4.14 \\
\hline Satisfaction with life (SWLS) & 10.00 & 30.00 & 20.78 & 5.31 \\
\hline Duration of diabetes (time from diagnosis/years) & 1.00 & 23.00 & 7.45 & 4.92 \\
\hline
\end{tabular}

$\mathrm{M}$ - arithmetic mean, SD - standard deviation

Table 2. Relationships between independent variables included in the study (Pearson's $r$ correlation coefficients)

\begin{tabular}{|c|c|c|c|c|}
\hline \multirow[t]{2}{*}{ Variables } & \multicolumn{4}{|c|}{ Pearson's $r$} \\
\hline & Age & BMI & $\begin{array}{l}\text { Duration } \\
\text { of diabetes }\end{array}$ & SWLS \\
\hline Age & 1 & $0.327^{\star *}$ & $0.372^{* *}$ & $0.159^{\star *}$ \\
\hline BMI & & 1 & $0.239^{\star *}$ & $-0.235^{\star *}$ \\
\hline Duration of diabetes & & & 1 & $-0.220^{\star *}$ \\
\hline Satisfaction with life (SWLS) & & & & 1 \\
\hline
\end{tabular}

Table 3. Frequency of consuming selected groups of food products among women aged 40-65 years with type 2 diabetes (descriptive statistics)

\begin{tabular}{|c|c|c|c|c|c|c|c|}
\hline \multirow[t]{2}{*}{ Food products } & \multicolumn{7}{|c|}{ Descriptive statistics } \\
\hline & M & SD & Me & Min & Max & Q25 & Q75 \\
\hline Vegetables & 5.18 & 1.37 & 5.00 & 2.00 & 7.00 & 4.00 & 6.00 \\
\hline Green vegetables & 4.69 & 1.34 & 5.00 & 1.00 & 7.00 & 4.00 & 6.00 \\
\hline Legume seeds & 3.13 & 1.58 & 3.00 & 1.00 & 7.00 & 2.00 & 4.00 \\
\hline Fruit & 4.81 & 1.60 & 5.00 & 1.00 & 7.00 & 4.00 & 6.00 \\
\hline Whole-wheat products & 3.66 & 1.70 & 3.00 & 1.00 & 7.00 & 3.00 & 5.00 \\
\hline White whole-wheat products & 4.46 & 1.81 & 4.00 & 1.00 & 7.00 & 3.00 & 6.00 \\
\hline Whole-fat milk and cottage cheese & 3.08 & 1.91 & 3.00 & 1.00 & 7.00 & 1.00 & 4.00 \\
\hline Semi-fat or skimmed milk and cottage cheese & 3.76 & 1.68 & 4.00 & 1.00 & 7.00 & 3.00 & 5.00 \\
\hline Yellow cheeses & 3.39 & 1.70 & 3.00 & 1.00 & 7.00 & 2.00 & 4.50 \\
\hline Eggs & 3.70 & 1.32 & 4.00 & 1.00 & 6.00 & 3.00 & 5.00 \\
\hline Sea fish & 3.30 & 1.32 & 3.00 & 1.00 & 7.00 & 2.00 & 4.00 \\
\hline Meat, pork cold-cuts & 4.71 & 1.59 & 5.00 & 2.00 & 7.00 & 3.00 & 6.00 \\
\hline Meat, poultry cold-cuts & 4.42 & 1.61 & 5.00 & 1.00 & 7.00 & 4.00 & 5.50 \\
\hline Butter & 4.21 & 2.17 & 4.00 & 1.00 & 7.00 & 2.00 & 6.00 \\
\hline Nuts, almonds & 3.46 & 1.91 & 3.00 & 1.00 & 7.00 & 2.00 & 5.00 \\
\hline Margarines with plant sterols & 3.58 & 2.27 & 3.00 & 1.00 & 7.00 & 1.00 & 6.00 \\
\hline Fast foods / salty snacks & 2.89 & 1.67 & 3.00 & 1.00 & 7.00 & 1.00 & 4.00 \\
\hline Sweets, pastries & 3.13 & 1.89 & 3.00 & 1.00 & 7.00 & 2.00 & 4.00 \\
\hline Sweetened sodas & 3.36 & 1.94 & 3.00 & 1.00 & 7.00 & 2.00 & 5.00 \\
\hline Fruit juices & 3.27 & 2.02 & 3.00 & 1.00 & 7.00 & 1.00 & 5.00 \\
\hline Mineral water & 5.52 & 1.93 & 7.00 & 1.00 & 7.00 & 5.00 & 7.00 \\
\hline Alcoholic beverages & 2.14 & 1.32 & 2.00 & 1.00 & 7.00 & 1.00 & 2.00 \\
\hline
\end{tabular}


wheat products, whole-fat milk and cottage cheese, yellow cheeses, sea fish, nuts, margarine with plant sterols, fast foods, sweets and pastries, sweetened sodas, and fruit juices. Women usually reached for alcoholic beverages once a month $(\mathrm{Me}=2)$ (Table 3$)$.

Analysis of correlations between the examined variables and the frequency of consuming certain groups of food products showed that with increasing age, the frequency of consuming the following products also increased: green vegetables ( $p<0.001)$, fruit $(p<0.001)$, yellow cheeses $(p<0.01)$, nuts $(p<0.001)$, and soft margarines with plant sterols $(p<0.05)$, while the rate of consumption decreased in the case of: legume seeds $(p<0.001)$, whole-fat milk and dairy products $(p<0.001)$, eggs $(p<0.001)$, poultry meat and cold-cuts $(p<0.001)$, butter $(p<0.01)$, fast foods $(p<0.001)$, sweetened sodas and fruit juices $(p<0.05)$, as well as alcoholic beverages $(p<0.01)$.

As the time from diagnosis passed, the frequency of consuming the following products increased: legume seeds $(p<0.05)$, whole-fat milk and dairy products ( $p<0.001)$, yellow cheeses $(p<0.001)$, pork meat and cold-cuts $(p<0.05)$, sweets $(p<0.01)$, fast foods $(p<0.001)$, and alcoholic beverages $(p<0.01)$, while the rate of consuming the following decreased: green vegetables $(p<0.05)$, fish $(p<0.05)$, nuts $(p<0.05)$, and mineral water $(p<0.05)$.

As BMI increased, the frequency of consuming the following increased: yellow cheeses $(p<0.05)$, butter $(p<0.05)$, vegetable margarines $(p<0.001)$, sweets $(p<0.01)$, sweetened sodas $(p<0.001)$, and fruit juices $(p<0.01)$, while the frequency of consuming these products decreased: whole-fat dairy products $(p<0.001)$, semi-skimmed dairy products $(p<0.01)$, and mineral water $(p<0.05)$.

Along with the increase in the level of life satisfaction, the frequency of consuming the following increased: vegetables $(p<0.001)$, legume seeds $(p<0.001)$, fruit $(p<0.01)$, whole-wheat products $(p<0.001)$, semiskimmed and low-fat dairy products $(p<0.001)$, sea fish $(p<0.001)$, nuts $(p<0.001)$, and mineral water $(p<0.001)$, while the frequency of consuming these products decreased: white whole-wheat products $(p<0.001)$, yellow cheeses $(p<0.001)$, pork $(p<0.001)$ and poultry $(p<0.05)$ meat and cold-cuts, butter $(p<0.001)$, margarine $(p<0.001)$, sweets $(p<0.001)$, fast foods $(p<0.001)$, sweetened sodas $(p<0.001)$, fruit juices $(p<0.05)$, and alcoholic beverages $(p<0.01)$ (Table 4$)$.

\section{Discussion}

This research has shown nutritional deficiencies and the relationship between age, duration of disease, $\mathrm{BMI}$, and the level of life satisfaction as well as the rate of consuming certain groups of food products among women aged $40-65$ years with type 2 diabetes. We also demonstrated that the increase in BMI along with age and duration of the disease was associated with a decrease in the level of life satisfaction, thus confirming the gradual decline in the quality of women's life in the course of diabetes.

An essential part of the therapeutic process in diabetes is dietotherapy, which aims at improving metabolic rates, glycaemic control, optimisation of lipid profile and blood pressure, as well as improvement in overall health and quality of life [19]. In diabetes, nutrition similar to the Mediterranean nutrition model is recommended, with a high share of vegetables and fruits, whole-grain cereals, fish, olive oil, and nuts, and low consumption of animal fats and red meat [17, 22, 29]. Meanwhile, among women with type 2 diabetes, nutritional deficiencies have been found, particularly regarding the low frequency of consuming recommended products with high nutrient density, including: vegetables, fruit, legume seeds, whole-wheat cereals, dairy products with reduced fat content, and nuts. This can result in a reduced supply of dietary fibres, antioxidants, and group B vitamins as well as calcium and unsaturated acids, thus increasing the risks to health.

A key aspect of dietary diabetes therapy is avoiding products with high glycaemic index and instead favouring products with medium and low GI [30, 31]. The basis of the diet, in addition to whole-wheat cereal products, should be vegetables and fruit, low-glycaemic sources of insoluble and soluble fibre fractions, including pectin reducing postprandial glycaemia and improving blood lipid profile, as well as bioactive substances, including antioxidants (vitamin C, carotenoids, polyphenols) [32]. In other studies, for example, among American patients, inadequate intake of fruit and vegetables among diabetic patients has also been described (five portions of vegetables and fruit accounted for only $26 \%$ of people), similarly as in our study [16]. A low intake of vegetables was also demonstrated in another Polish study among diabetic patients, in which only $8.2 \%$ of patients with type 1 diabetes consumed them several times a day [33]. Also, in another study it was found that fruit was consumed by $18 \%$ of women with type 2 diabetes more often than once a day [34]. Insufficient frequency of vegetable consumption (68\% daily) and fruit ( $85 \%$ daily) was also described among patients with type 2 diabetes treated at clinics in the Małopolska region [35]. The cited studies correspond to the results of studies among people with metabolic syndrome, who also had deficiencies in dietary fibre [36].

In rational nutrition for people with diabetes, both animal products (lean meat, fish, and skimmed dairy products) as well as foods from plants (legume seeds) are recommended as a source of protein. In our research, among the dairy products, patients more often chose products with reduced fat content, but at a similar frequency, they reached for white and red meat. Fish was usually selected several times a month, which may lower the supply of omega 3 PUFAs, playing an essential role in optimising 
Table 4. Correlations between age, BMI, duration of disease, level of life satisfaction, and the frequency of consuming food groups among women aged 40-65 years with type 2 diabetes (Spearman's $R$ coefficient)

\begin{tabular}{|c|c|c|c|c|}
\hline \multirow[t]{2}{*}{ Food products } & \multicolumn{4}{|c|}{ Spearman's $R$} \\
\hline & Age & BMI & $\begin{array}{l}\text { Duration } \\
\text { of illness }\end{array}$ & SWLS \\
\hline Vegetables & 0.020 & $-0.246^{\star \star \star}$ & -0.111 & $0.553^{* \star *}$ \\
\hline Green vegetables & $0.267^{* * *}$ & -0.095 & $-0.130^{\star}$ & $0.479^{* \star \star}$ \\
\hline Legume seeds & $-0.198^{\star * *}$ & -0.106 & $0.143^{*}$ & $0.216^{\star * *}$ \\
\hline Fruit & $0.528^{* * *}$ & 0.088 & -0.081 & $0.154^{* \star}$ \\
\hline Whole-wheat products & -0.077 & -0.053 & -0.066 & $0.322^{\star \star *}$ \\
\hline White whole-wheat products & 0.061 & -0.080 & 0.084 & $-0.334^{\star * *}$ \\
\hline Whole-fat milk and cottage cheese & $-0.271^{\star * *}$ & $-0.198^{\star * \star}$ & $0.999^{\star \star *}$ & -0.067 \\
\hline Semi-fat or skimmed milk and cottage cheese & 0.095 & $-0.181^{\star *}$ & -0.029 & $0.239^{\star \star *}$ \\
\hline Yellow cheeses & $0.170^{\star *}$ & $0.168^{\star *}$ & $0.235^{\star * \star}$ & $-0.291^{\star \star *}$ \\
\hline Eggs & $-0.295^{\star \star *}$ & -0.040 & -0.095 & 0.105 \\
\hline Sea fish & 0.081 & -0.026 & $-0.130^{*}$ & $0.259^{\star * *}$ \\
\hline Pork meat and cold-cuts & 0.021 & 0.073 & $0.142^{*}$ & $-0.461^{\star * *}$ \\
\hline Poultry meat and cold-cuts & $-0.190^{\star * *}$ & 0.080 & -0.083 & $-0.149^{\star}$ \\
\hline Butter & $-0.180^{\star *}$ & $0.126^{\star}$ & -0.107 & $-0.325^{* * *}$ \\
\hline Nuts, almonds & $0.279^{\star * *}$ & 0.069 & $-0.127^{*}$ & $0.235^{\star * *}$ \\
\hline Margarines with plant sterols & $0.134^{*}$ & $0.206^{\star * *}$ & 0.043 & $-0.320^{\star * *}$ \\
\hline Fast foods / salty snacks & $-0.208^{\star \star *}$ & 0.067 & $0.181^{\star *}$ & $-0.313^{* * *}$ \\
\hline Sweets and pastries & -0.118 & $0.170^{* *}$ & $0.214^{* * *}$ & $-0.318^{\star * *}$ \\
\hline Sweetened sodas & $-0.140^{\star}$ & $0.322^{\star * *}$ & 0.033 & $-0.200^{\star * *}$ \\
\hline Fruit juices & $-0.128^{*}$ & $0.177^{* *}$ & -0.059 & $-0.124^{*}$ \\
\hline Mineral water & -0.027 & $-0.143^{\star}$ & $-0.141^{\star}$ & $0.305^{\star * *}$ \\
\hline Alcoholic beverages & $-0.163^{\star \star}$ & -0.082 & $0.161^{\star *}$ & $-0.161^{\star *}$ \\
\hline
\end{tabular}

the lipid profile of the blood. A different study suggests compounds of vitamin D deficiency (its source is sea fish) with the risk of type 2 diabetes [37] and indicated the likelihood of vitamin D deficiency, among others, in patients with diabetes [38]. The importance of dairy products is related to the supply of calcium, and one Korean study has shown a negative correlation between calcium intake and the incidence of type 2 diabetes [39]. In another investigation among women with type 2 diabetes from Małopolska, consumption of pork was observed in $23 \%$, poultry meat in $62 \%$, and fatty sausages in $13 \%$ of patients [35].

Improvement in metabolic parameters, including the lipid profile of the blood, is favoured by a diet with restriction of saturated fatty acids [5]. Meanwhile, in our research, more frequent consumption of animal fats (butter) than vegetable oils (nuts and soft margarine) was found. An additional study among diabetic patients in Krakow also showed more frequent consumption of animal than vegetable fat, lack of interest in the fat content of products $(32.0 \%)$, and not restricting products containing cholesterol (80.0\%) [40]. Meanwhile, studies have shown a relationship between eating butter and fatty cheeses and the risk of developing diabetes [41].
Avoiding sweets, pastries, and sweetened sodas, as recommended in diabetic nutrition, is justified by the need to significantly reduce the intake of simple sugars, high index glycaemic products, as well as trans-unsaturated fatty acid isomers. The research confirmed a relationship between the consumption of sweetened beverages, metabolic syndrome, and type 2 diabetes $[42,43]$. The literature on the subject confirms the high prevalence of consuming sweets and pastries in various groups of diabetic patients. Regular consumption of sweets was demonstrated in the group of patients with type 1 and type 2 diabetes, with an indication to reach for sweets at most, several times a month (42.8\% with type 1 diabetes and $62.9 \%$ with type 2 diabetes). Patients also consumed these products more often, i.e. several times a week (34.7\% with type 1 diabetes and $22.2 \%$ with type 2 diabetes) and daily (20.4\% with type 1 diabetes and 7.4\% with type 2 diabetes) [33]. Increased consumption of sweets was also described among the Małopolska group of diabetic patients [15, 44, 45]. Non-consumption of sweets was declared by only $18 \%$ in the case of another group of women with diabetes from Małopolska [35]. Alcohol contraindicated for people with diabetes was usually consumed sporadically, which 
should be assessed positively because alcohol increases the risk of glycaemic deregulation [46].

The discussed research among women with type 2 diabetes also showed statistically significant relationships between age, duration of disease, BMI, and level of life satisfaction, as well as the frequency of consuming certain groups of food products. The observed trends were not entirely unambiguous but showed a specific direction. With increasing age, the frequency of consuming recommended products (including green vegetables and fruits, nuts, and margarine with plant sterols) increased, while the frequency of consuming non-recommended products (including fast foods, sweetened sodas) decreased, which may indicate an increase in health consciousness regarding the significance of rational dietary choices for health. In turn, with the duration of the disease, there was a tendency towards less intensive rational food choices. The rate of consuming products rich in saturated fatty acids (e.g. high-fat dairy products, pork, and cold-cuts), simple sugars, and trans isomers (sweets, fast foods) increased, and the frequency of consuming the recommended products decreased (green vegetables, fish, nuts), which may indicate a decrease in motivation to make rational dietary choices in the course of the disease. Improper dietary choices in the course of diabetes may limit the effectiveness of therapy and increase the risk of complications, which corresponds to health risks that occur in addition to diabetes (excessive body mass, hyperlipidaemia, hypertension, etc.). Different studies among adults have also shown differences in preferences and eating habits depending on age, in such a way that they could be a factor influencing the increase in BMI and adipose tissue as well as the risk of metabolic diseases (lipid and carbohydrate), with co-existing obesity [47]. Studies conducted in the Polish population (subjects above the age of 20) in 2013-2014 as part of the WOBASZ II programme confirmed the prevalence of metabolic disorders among women, including hypercholesterolaemia (55.3\%), hypertension $(41.7 \%)$, diabetes (9.6\%), and obesity (27.2\%) as well as nutritional deficiencies related to them [48].

The relationships between the frequency of food consumption and BMI demonstrated in the discussed research, indicating positive $\mathrm{BMI}$ correlations with the frequency of consuming, among others: yellow cheeses, butter, sweets, and sweetened sodas, confirmed the participation of high energy density products in the development of excessive body mass. The consumption of products with a high content of saturated fatty acids (yellow cheeses and butter) and simple sugars (sweets and carbonated beverages) may increase the energy intake in the food rations as well as the risk of developing excessive body mass (and an increase in BMI). The correlations between high consumption of sweetened sodas and the development of overweight and obesity has been confirmed in epidemiological and clinical studies $[43,49]$. Another study also confirmed the importance of environmental (low physical activity and nutritional errors) and socio-economic (easy access to cheaper, highly processed, and high-calorie foods) factors in the development of overweight and obesity [50].

The discussed research also showed a tendency to increase the scale of rational food choices along with the increase in the level of life satisfaction; in particular, related to the more frequent consumption of recommended products, including: vegetables, legume seeds, fruit, whole-wheat cereals, skimmed dairy products, sea fish, and nuts, and less frequent consumption of less-recommended products, including: light cereals, pork meat and cold-cuts, sweets, fast food, sweetened sodas, and alcoholic beverages. These behaviours fit into the list of rational dietary choices, favouring the balance of carbohydrate metabolism and optimising the lipid profile of the blood, due to the functional properties of the nutrients contained in them. The proven regularities, indicating a more rational model of nutrition for people with a high level of life satisfaction, are justified by the characteristics of this dimension. A high level of life satisfaction, i.e. the cognitive aspect of satisfaction from life, is a vital health resource that stimulates pro-health behaviours, also within the field of balanced nutrition [25]. The relationships indicated in the discussed studies can be explained by the relationships between more rational dietary choices and the improvement of health, which indirectly translates into better quality of life (and a higher level of life satisfaction) and higher motivation to make more beneficial food choices by women with higher life satisfaction. The trends described in our research also refer to the results of other studies, including among women at perimenopausal age [26-28]. Correlations between life satisfaction and some health determinants, including nutrition, have also been confirmed in Chilean research [51]. A high level of the sense of life satisfaction seems to be an important personal resource conducive to ongoing health care, including more rational dietary behaviours of women with diabetes, which is all the more important because the recommended dietary restrictions (limitations) affect the quality of life of women with type 2 diabetes [52]. In addition, type 2 diabetes generally negatively affects the quality of life of patients, to a greater extent in women than in men [53].

\section{Conclusions}

Among women with type 2 diabetes mellitus, the found nutritional deficiencies regarded, in particular, insufficient frequency of consuming certain recommended groups of food products, including vegetables, fruit, legume seeds, whole-wheat cereals, low-fat dairy products, and nuts, which can lower the nutritional value and pro-health diet. 
Among women with type 2 diabetes, we found sig nificant relationships between age, duration of disease, $\mathrm{BMI}$, and the level of life satisfaction, as well as the frequency of consuming certain groups of food products.

The scale of rational dietary choices among women with type 2 diabetes increased along with age and feeling of life satisfaction, and decreased from time of diagnosis and along with the increase in BMI.

In the health education of women with type 2 diabetes, conducive to the optimisation of therapeutic procedures, factors conditioning dietary choices, including age, time from diagnosing the disease, BMI, and life satisfaction, should be taken into account.

\section{Disclosure}

The authors report no conflict of interest.

\section{References}

1. Kolb H, Martin S. Environmental/lifestyle factors in the pathogenesis and prevention of type 2 diabetes. BMC Med 2017; 15: 131.

2. Wu Y, Ding Y, Tanaka Y, Zhang W. Risk factors contributing to type 2 diabetes and recent advances in the treatment and prevention. Int J Med Sci 2014; 11: 1185-1200.

3. Torimoto K, Okada Y, Tanaka Y. Type 2 Diabetes and Vascular Endothelial Dysfunction. J UOEH 2018; 40: 65-75.

4. Vaidya V, Gangan N, Sheehan J. Impact of cardiovascular complications among patients with Type 2 diabetes mellitus: a systematic review. Expert Rev Pharmacoecon Outcomes Res 2015; 15: 487-497.

5. Misra A, Singhal N, Khurana L. Obesity, the metabolic syndrome, and type 2 diabetes in developing countries: role of dietary fats and oils. J Am Coll Nutr 2010; 29 (Suppl 3): 289-301.

6. Hu FB. Globalization of diabetes: the role of diet, lifestyle, and genes. Diabetes Care 2011; 34: 1249-1257.

7. Riobó SP. Obesity and diabetes. Nutr Hosp 2013; 28 (Suppl 5): 138-143.

8. Abdelhafiz AH, Sinclair AJ. Management of type 2 diabetes in older people. Diabetes Ther 2013; 4: 13-26.

9. Miazgowski T. Otyłość a cukrzyca [Obesity and Diabetes]. Fam Med Prim Care Rev 2012; 14: 462-467.

10. Gray N, Picone G, Sloan F, Yashkin A. Relation between BMI and diabetes mellitus and its complications among US older adults. South Med J 2015; 108: 29-36.

11. Stachowiak G, Pertyński T, Pertyńska-Marczewska M. Metabolic disorders in menopause. Prz Menopauzalny 2015; 1: 59-64.

12. Stachowiak G, Stetkiewicz T, Pertyński T. Diabetes mellitus in menopausal women. Prz Menopauzalny 2011; 3: 173-180.

13. Baranik A, Ostrowska L. Praktyczne zalecenia dotyczące żywienia chorych z cukrzycą typu 2 i otyłością [Practical Recommendations Regarding the Nutrition of Patients with Type 2 Diabetes and Obesity]. Forum Zab Metab 2011; 2: 222-230.

14. Biernat E, Piątkowska M. Zdrowotne rekomendacje Światowej Organizacji Zdrowia a rekreacyjna aktywność fizyczna Polaków [Pro-health Recommendations of the World Health Organization and Recreational Physical Activity Among Poles]. Med Sport 2013; 29: 255-264.

15. Mędrela-Kuder E. Prawidłowa dieta w cukrzycy typu 2 jako forma rehabilitacji chorych [Proper Diet in Type 2 Diabetes as a Form of Rehabilitation in Patients]. Rocz Panstw Zakl Hig 2011; 62: 219-223.

16. Campbell HM, Khan N, Cone C, Raisch DW. Relationship between diet, exercise habits, and health status among patients with diabetes. Res Social Adm Pharm 2011; 7: 151-161.

17. Khazrai YM, Defeudis G, Pozzilli P. Effect of diet on type 2 diabetes mellitus: a review. Diabetes Metab Res Rev 2014; 30 (Suppl 1): 24-33.

18. Adolf C, Freibothe I, Seissler J, Lechner A. Current concepts in diagnostics and therapy of diabetes mellitus. Radiologe 2015; 55: 295-298.
19. Standards of Medical Care In Diabetes - 2014. American Diabetes Association. Diabetes Care 2014; 37 (Suppl 1): 14-80.

20. Lumb A. Diabetes and exercise. Clin Med 2014; 14: 673-676.

21. Hemmingsen B, Gimenez-Perez G, Mauricio D, et al. Diet, physical activity or both for prevention or delay of type 2 diabetes mellitus and its associated complications in people at increased risk of developing type 2 diabetes mellitus. Cochrane Database Syst Rev 2017; 4: 12.

22. Barrera M, Toobert DJ, Strycker LA, et al. Interwencje oparte na założeniach zmiany zachowań u kobiet chorych na cukrzycę typu 2 [Interventions Based on the Assumptions of Behavioral Change in Women with Type 2 Diabetes]. Diabetol Dyplom 2011; 8: 33-38.

23. Micha R, Peñalvo JL, Cudhea F, et al. Association Between Dietary Factors and Mortality From Heart Disease, Stroke, and Type 2 Diabetes in the United States. JAMA 2017; 317: 912-924.

24. Remick AK, Polivy J, Pliner P. Internal and external moderators of the effect of variety on food intake. Psychol Bull 2009; 135: 434-451.

25. Juczyński Z. Narzędzia pomiaru w psychologii i promocji zdrowia [Measuring Tools in Psychology and Health Promotion]. Wyd. PTP, Warszawa 2012.

26. Gacek M. Selected individual differences as predictors of milk product consumption in a group of perimenopausal women in the light of health hazards. Prz Menopauzalny 2013; 17: 300-306.

27. Gacek M. Selected individual differences as determining factors of cereal product, fruit and vegetable consumption among perimenopausal women, in light of health hazards. Prz Menopauzalny 2013; 17: 385-391.

28. Gacek M. Individual differences as predictors of dietary patterns among menopausal women with arterial hypertension. Prz Menopauzalny 2014; 18: 101-108.

29. Esposito K, Maiorino MI, Bellastella G, et al. Mediterranean diet for type 2 diabetes: cardiometabolic benefits. Endocrine 2017; 56: 27-32.

30. Thomas D, Elliott E. The use of low-glycemic index diets in diabetes control. Br J Nutr 2010; 104: 797-802.

31. Kulczyński B, Gramza-Michałowska A. Znaczenie indeksu i ładunku glikemicznego w zapobieganiu rozwoju chorób sercowo-naczyniowych [The Importance of Index and Glycaemic Load in Preventing the Development of Cardiovascular Diseases]. Probl Hig Epidemiol 2015; 96 : 51-56.

32. Barclay A, Gilbertson H, Marsh K, Smart C. Dietary management in diabetes. Aust Fam Physician 2010; 39: 579-583.

33. Szewczyk A, Białek A, Kukielczak A, et al. Ocena sposobu żywienia osób chorujących na cukrzycę typu 1 i 2 [Evaluation of Eating Habits in $\mathrm{Pa}$ tients with Type 1 and Type 2 Diabetes]. Probl Hig Epidemiol 2011; 92: 267-271.

34. Włodarek D, Gąbska D. Zwyczaje żywieniowe osób chorych na cukrzyce typu 2 [Eating Habits Among Patients with Type 2 Diabetes]. Diabetol Prakt 2010; 11: 17-23.

35. Mędrela-Kuder E, Bis H. Porównanie aktywności fizycznej i diety u kobiet i mężczyzn chorych na cukrzycę typu 2 [Comparing Physical Activity and Diet in Women and Men with Type 2 Diabetes]. Med Og Nauk Zdr 2014; 20: 31-33.

36. Bator E, Bienkiewicz M, Kaczor K, et al. Ocena stanu odżywienia oraz sposobu żywienia osób ze zdiagnozowanym zespołem metabolicznym [Assessment of Nutrition Status and Eating Habits Among Patients with Diagnosed Metabolic Syndrome]. Probl Hig Epidemiol 2014; 95: 948-955.

37. Issa CM. Vitamin D and Type 2 Diabetes Mellitus. Adv Exp Med Bio 2017; 996: 193-205.

38. Matyjaszek-Matuszek B, Lenart-Lipińska M, Woźniakowska E. Clinical implications of vitamin D deficiency. Prz Menopauzalny 2015; 14: 75-81.

39. Oh JM, Woo HW, Kim MK, et al. Dietary total, animal, vegetable calcium and type 2 diabetes incidence among Korean adults: The Korean Multi-Rural Communities Cohort (MRCohort). Nutr Metab Cardiovasc Dis 2017; 27: 1152-1164.

40. Mędrela-Kuder E. Wybrane zwyczaje żywieniowe w grupie kobiet z nadwagą lub otyłością [Selected Eating Habits in a Group of Obese or Overweight Women]. Rocz Panstw Zakl Hig 2005; 56: 371-377.

41. Guasch-Ferré M, Becerra-Tomás N, Ruiz-Canela M, et al. Total and subtypes of dietary fat intake and risk of type 2 diabetes mellitus in the Prevención con Dieta Mediterránea (PREDIMED) study. Am J Clin Nutr 2017; 105: 723-735.

42. Kłosiewicz-Latoszek L, Cybulska B. Cukier a ryzyko otyłości, cukrzycy i chorób sercowonaczyniowych [Sugar and health hazard of obesity, 
diabetes mellitus and cardiovascular diseases]. Probl Hig Epidemiol 2011; 92: 181-186.

43. Malik VS, Popkin BM, Bray GA, et al. Sugar-sweetened beverages, obesity, type 2 diabetes mellitus, and cardiovascular disease risk. Circulation 2010; 121: 1356-1364.

44. Gacek M. Wybrane parametry somatyczne, stan zdrowia i zachowania żywieniowe w grupie chorych na cukrzycę typu 2 [Selected Somatic Parameters, Health State and Nutrition Habits Among a Grouop of Type 2 Diabetes Patients]. Endokrynol Otył Zab Przem Mat 2011; 7: 172-178.

45. Gacek M, Frączek B. Wybory żywieniowe i inne aspekty stylu życia grupy osób z cukrzycą typu 1 [Nutrition Choices and Other Aspects of Lifestyle Among a Group of Patients with Type 2 Diabetes]. Probl Hig Epidemiol 2017; 98: 33-39.

46. Joosten MM, Chiuve SE, Mukamal KJ, et al. Changes in alcohol consumption and subsequent risk of type diabetes in men. Diabetes 2011; 60: 74-79.

47. Adamska E, Ostrowska L, Adamska E, et al. Różnice w nawykach i preferencjach żywieniowych osób dorosłych w zależności od wieku [Differences in Nutrition Preferences Among Adults According to Age]. Rocz Panstw Zakl Hig 2012; 63: 73-81.

48. Waśkiewicz A, Szcześniewska D, Szostak-Węgierk D, et al. Are dietary habits of the Polish population consistent with the recommendations for prevention of cardiovascular disease? - WOBASZ II Project. Kardiol Pol 2016; 74: 969-977.

49. Bermudez OI, Gao X. Greater consumption of sweetened beverages and added sugarsis associated with obesity among US young adults. Ann Nutr Metab 2010; 57: 211-218.

50. Godziejewska-Zawada M. Obesity and diabetes in menopause: prevention and therapeutic approach. Prz Menopauzalny 2013; 1: 5-9.

51. Schnettler B, Lobos G, Orellana L, et al. Analyzing Food-Related Life Satisfaction and other Predictors of Life Satisfaction in Central Chile. Span J Psychol 2015; 18: 38.

52. Rogon I, Kasprzak Z, Szcześniak Ł. Perceived quality of life and acceptance of illness in people with type 2 diabetes mellitus. Prz Menopauzalny 2017; 16: 79-85.

53. Svenningsson I, Marklund B, Attvall S, Gedda B. Type 2 diabetes: perceptions of quality of life and attitudes towards diabetes from a gender perspective. Scand J Caring Sci 2011; 25: 688-695. 